\title{
Topical dutasteride with microneedling in treatment of male
}

\section{androgenetic alopecia}

\author{
Essam A. Nada, Reham Ezz El-Dawla, Wafa M. Abd El-Maged, Marwa A. Abo Elmagd
}

Department of Dermatology, Venereology and Andrology

\section{Introduction}

Male androgenetic alopecia (AGA) is the most common type of hair loss in men. It accounts for more than $90 \%$ of all cases of alopecia in men ${ }^{(1)}$. It occurs when genetically predisposed men are exposed to androgens. AGA may negatively affect patient's quality of life and can lead to social and job-related problems ${ }^{(2)}$. AGA can also cause indirect physical harm, such as sunburn as a result of hair loss and exposure to ultraviolet light ${ }^{(3)}$. AGA may also be associated with increased incidence of hypertension, hypercholesterolemia, and myocardial infarction ${ }^{(4)}$.

The only FDA approved therapies for treatment are limited to topical minoxidil and oral FIN with limited efficacy (40-60\%) ${ }^{(5)}$. As multiple factors are implicated in the pathogenesis of AGA and the existing conventional therapies (i.e. FIN and minoxidil) fail to target all of them; the demand for new treatment techniques for AGA is growing ${ }^{(6)}$.

Dutasteride (DST) is a dual $5 \alpha-$ reductase inhibitor, with some reports about the use of oral DST in the treatment of AGA in men ${ }^{(7)}$. Hesitancy about the widespread use of oral DST in the treatment of male AGA results from its potential side effects on erectile, ejaculatory functions and fertility (3). Mesotherapy using DST has been used in patients with AGA with promising results ${ }^{(\mathbf{8}, \mathbf{9})}$. It is believed that systemic absorption after mesotherapy is equal to after oral DST because the scalp is highly vascular. So the possibility of using DST topically with scalp MN would have some advantages ${ }^{(\mathbf{1 0})}$.

Microneedling (MN) is a relatively new minimally invasive procedure involving superficial and controlled puncturing of the skin by rolling with miniature fine needles ${ }^{(11)}$. The use of $\mathrm{MN}$ in combination with minoxidil showed promising results in treatment of AGA ${ }^{(6)}$. Furthermore; the addition of $\mathrm{MN}$ to minoxidil and oral FIN improved AGA in patients who were resistant to minoxidil and oral FIN (12). To the best of our knowledge; the use of MN in combination with DST hasn't been previously reported. This study was designed to evaluate the efficacy and safety of topical DST with $\mathrm{MN}$ in treatment of male AGA.

\section{Patients and methods}

This prospective, randomized, clinical study was approved by Ethical and Research committees at Faculty of Medicine, Sohag University. An informed written consent was obtained from all participants. The study included 30 male patients complaining of progressive hair loss diagnosed as AGA attending at Dermatology outpatient clinics at Sohag University Hospitals, Faculty of Medicine, Sohag University.

\section{Exclusion criteria}

" Patients with other forms of alopecia including telogen effluvium, alopecia areata.

" Patients with dermatological or systemic illness known to cause diffuse hair loss (as thyroid disorders or anemia). 
Patients received minoxidil, any hair growth promoters in the past six months or those underwent surgical hair transplantation.

" Patients on hormonal, androgenic or anti androgenic medications cytotoxic, and inhibitors of CYP3A4 (ketoconazole, verapamil, diltiazem, cimetidine, ciprofloxacin).

" Patients with systemic disease (diabetes, history of stroke, history of any thromboembolic disorders, seizure disorders)

" Patients on anticoagulant medications (aspirin, warfarin and heparin), skin disease with Koebner's phenomenon, since these were the general contraindications for $\mathrm{MN}$.

" Patients suffering from decreased libido, ejaculatory or erectile dysfunction.

Methods: All patients were subjected to:

\section{I- Initial evaluation}

Personal history including age, occupation, marital status, special habits of medical importance and residency were reported. History of hair loss including onset, course and duration of hair loss, site of hair loss, and use of hair care cosmetics (dying, bleaching, and straightening) was discussed with all patients. History of other skin diseases, systemic diseases or any medications was documented. Family history of AGA was reported. Full general examination, searching for any signs of anemia (e.g. pallor, tachycardia and red glassed tongue) was done. Scalp examination for any signs of inflammation, scales, erythema or scarring was performed.

\section{II- Evaluation of hair loss:}

II.1- Pull test: It was done by grasping a small clump about 60 hairs in the index, middle and thumb and pulling hairs gently but with firm pressure. The shed hairs were counted. Normal shedding is 6 or fewer hairs shed and active shedding is more than 6 hairs shed ${ }^{(\mathbf{1 3})}$.

II.2- Grading of AGA: Patients were graded as one of the 7 stages according to Norwood-Hamilton scale (14)

II.3- Digital photography: All patients were digitally photo documented before and after six months of treatment. A picture of the fronto-parietal region was obtained in each patient.

II.4- Trichoscopy: The trichoscope used in the current study was an epiluminescene digital microscope (compareview A/V; Version 1.5.09). A magnification of (x 50) was used to be able to see the density of the hair follicles, vellus and terminal hairs. A magnification of (x 200) was done to be able to see the caliber of the hair shaft. The frontal area of the scalp of each patient underwent tricoscopic evaluation, before and six months after treatment. Trichoscopic images were taken at the same specific area in the frontal area of each patient.

\section{III- Laboratory investigations}

Serum testosterone and dihydrotestosterone (DHT) were performed for patients who received DST before starting therapy and one week after last session. Blood sample was collected in standard plain tubes and serum was separated and test was done by chemi-luminscent microparticles immunoassay using the Architect i system ( $2^{\text {nd }}$ generation). The normal reference ranges were $(0.47-9.8 \mathrm{ng} / \mathrm{ml})$ for testosterone and (250- $990 \mathrm{pg} / \mathrm{ml})$ for DHT.

\section{IV- Treatment procedues}

IV.1) Study groups: This study included 30 male patients with AGA 
who were randomly divided into 2 groups, each containing 15 patients. Group 1 underwent MN followed by topical application of pure DST (0.02\%). Group 2 underwent $\mathrm{MN}$ only.

IV.2) Microneedling: was done using dermapen, which is a pen like instrument with a handle, a disposable needle cartridge, having 12 needles arranged in rows, and a power button to turn the machine on and off. It has guides to adjust needle length (turning the guide clockwise, the needle length will be longer ranging from $(0.25 \mathrm{~mm}$ to $2 \mathrm{~mm}$ maximum).

The frontal area of the scalp of each patient of the two groups was anaesthetized using 10\% lidocaine spray. The affected area of the scalp was stretched and MN was carried out in vertical and horizontal directions until mild erythema was noted. The used needle length was $1.5 \mathrm{~mm}$.

IV.3) Dutasteride application: was done for group one only.

The used DST was medical curemesohair vials (purchased from spain). Each vial contains $5 \mathrm{ml}$ of pure (DST 0.02\%). After $\mathrm{MN}$ in group 1; topical application of pure DST $0.02 \%$ was done drop by drop to a maximum of $2 \mathrm{ml}$ on the treated site of the scalp then followed by MN, in the same directions.

IV.4) Treatment schedule: 13 sessions were done according to the following schedule:

V Once every week for eight weeks (week 0, 1, 2, 3, 4, 5, 6, 7).

$\checkmark$ Once every two weeks for one month (week 9, 11).

v Once every month for three months (week 15, 19, 23).

V- Treatment efficacy assessment: Assessment was done monthly and one week after the last session ( $24^{\text {th }}$ week) depending on:

V.1) Grading scale: according to Norwood-Hamilton grading scale.
V.2) Photographic assessment: Digital photos of the affected region were obtained from patients of the two groups before starting treatment (baseline) and at the end of treatment .

V.3) Phototrichoscope: All patients of the two groups underwent trichoscopic evaluation. Hair images were taken at 50x and 200x fold magnifications at the same affected area in the scalp of each patient before and after six months of treatment with (measurements of the hair density, hair thickness and terminal to vellus hair ratio).

V.4) Patient's self-assessment (Hair growth questionnaire):

Patients assessed their scalp hair at the end of the study using a validated hair growth questionnaire containing four questions on treatment efficacy and three questions on satisfaction with appearance ${ }^{(\mathbf{1 5})}$.

V.5) Investigator assessment: The hair density in the fronto-parietal region was compared to that observed before treatment using a 7-point rating scale: greatly decreased $(-3)$, moderately decreased (-2), slightly decreased ( -1$)$, no change (0), slightly increased $(+1)$, moderately increased $(+2)$, and greatly increased $(+3)^{(\mathbf{1 6})}$.

VI- Evaluation of treatment safety and tolerability:

VI.1) Local side effects: Patients were evaluated for local side effects including pain, headache, itching, infection, ecchymosis, itching and puffed eyes.

VI.2) Systemic side effects: Patients were evaluated for sexual disturbance (libido, erectile and ejaculatory functions), and breast enlargement and tenderness.

VI.3) Hormonal disturbance: Serum levels of testosterone and DHT were evaluated in group 1 before starting treatment and at the end of sessions.

Statistical analysis: 
$\mathrm{V}$ Data was analyzed using STATA intercooled version 12.1.

$\checkmark$ Numerical data were presented as mean and standard deviation (SD) values, for parametric numerical data, while Median and range for non-parametric numerical data.

$\mathrm{V}$ Student $\mathrm{T}$ test was used to assess the statistical significance of the difference between two study group means.

$\checkmark$ For parametric data: Paired t-test was used to assess the statistical significance of the difference between two means measured twice for the same study group.

$\checkmark$ For non-parametric data: Wilcoxon signed rank test was used assess the statistical significance of the difference of a non-parametric variables measured twice for the same study group, Mann Whitney test (U test) was used to assess the statistical significance of the difference of a non-parametric variable between two study groups.

V Spearman's correlation coefficient was used to determine correlations between Norwood Hamilton classification, age and duration of hair loss.

$\checkmark$ Qualitative data were presented as frequencies (n) and percentages $(\%)$; using either Chi square test or fisher exact test for comparisons.

$\vee P$ value $<0.05$ was considered significant.

\section{Results}

The study included 30 male patients diagnosed as having AGA. The study populations were classified into two groups: group 1 (MN with DST) and group 2 (MN alone). The mean age \pm SD of the patients was $26.37 \pm 4.31$ years, with $22(73.33 \%)$ of them from rural areas. The main demographic data in the study groups are shown in table 1. Family history of AGA was positive in $18(60 \%)$ of the patients. There was no statistically significant difference between the two groups as regards family history of AGA.

Table 1: Comparison between the study groups according to sociodemographic data.

\begin{tabular}{|c|c|c|c|c|}
\hline Variables & Group $1(n=15)$ & Group $2(n=15)$ & Statistical test & *P value \\
\hline $\begin{array}{l}\text { Age (years): } \\
\text { Mean } \pm \text { SD } \\
\text { Median (range) }\end{array}$ & $\begin{array}{l}27.0 \pm 4.41 \\
27(19-35)\end{array}$ & $\begin{array}{c}25.73 \pm 4.27 \\
25(20-32)\end{array}$ & Independent sample $t$ test & 0.43 \\
\hline $\begin{array}{l}\text { Smoking: } \\
\text { No } \\
\text { Cigarettes } \\
\text { Gauza }\end{array}$ & $\begin{array}{c}7(46.67 \%) \\
5(33.33 \%) \\
3(20 \%)\end{array}$ & $\begin{array}{c}10(66.67 \%) \\
4(26.67 \%) \\
1(6.67 \%)\end{array}$ & Chi square test & 0.44 \\
\hline $\begin{array}{l}\text { Residence: } \\
\text { Rural } \\
\text { Urban }\end{array}$ & $\begin{array}{l}12(80 \%) \\
3(20 \%)\end{array}$ & $\begin{array}{c}10(66.67 \%) \\
5(33.33 \%)\end{array}$ & Fisher exact test & 0.68 \\
\hline $\begin{array}{l}\text { Education: } \\
\text { Illiterate } \\
\text { Primary } \\
\text { High school } \\
\text { University }\end{array}$ & $\begin{array}{c}0 \\
2(13.33 \%) \\
4(26.67 \%) \\
9(60.00 \%)\end{array}$ & $\begin{array}{c}1(6.67 \%) \\
4(26.67 \% 0 \\
3(20 \%) \\
7(46.67 \%)\end{array}$ & Chi square test & 0.56 \\
\hline $\begin{array}{l}\text { Marital status: } \\
\text { Single } \\
\text { Married } \\
\text { Divorced }\end{array}$ & $\begin{array}{c}4(26.67 \%) \\
10(66.67 \%) \\
1(6.67 \%)\end{array}$ & $\begin{array}{c}6(40 \%) \\
9(60 \%) \\
0\end{array}$ & Chi square test & 0.48 \\
\hline
\end{tabular}

$* \mathrm{P}$ value $<0.05$ was significant.

Most of the patients (93.33\%) showed gradual onset of hair loss and progressive course was reported in all patients. There was no statistically significant difference between the two groups as regards onset, and duration of hair loss. The highest prevalence of hair loss was in the frontal and vertex regions (50\% of patients) (Table 2). 
SOHAG MEDICAL JOURNAL Vol. 22 No.1 Jan 2018
Topical dutasteride with microneedling in treatment Marwa A. Abo Elmagd

Table 2: Comparison between the study groups according to characters of hair loss.

\begin{tabular}{|c|c|c|c|c|}
\hline Variables & Group $1(n=15)$ & Group $2(n=15)$ & Statistical test & $\begin{array}{c}*{ }^{*} \mathbf{P} \\
\text { value }\end{array}$ \\
\hline $\begin{array}{l}\text { Onset: } \\
\text { Acute } \\
\text { Gradual }\end{array}$ & $\begin{array}{c}0 \\
15(100 \%)\end{array}$ & $\begin{array}{c}2(13.33 \%) \\
13(86.67 \%)\end{array}$ & Fisher exact test & 0.48 \\
\hline $\begin{array}{l}\text { Course: } \\
\text { Progressive }\end{array}$ & $15(100 \%)$ & $15(100 \%)$ & & \\
\hline $\begin{array}{l}\text { Duration of illness: } \\
\text { Mean } \pm \text { SD } \\
\text { Median (range) }\end{array}$ & $\begin{array}{c}5.66 \pm 2.23 \\
6(3-10) \\
\end{array}$ & $\begin{array}{c}4.33 \pm 2.23 \\
4(2-8) \\
\end{array}$ & Mann-Whitney test & 0.10 \\
\hline $\begin{array}{l}\text { Site of hair loss: } \\
\text { Front } \\
\text { Front and vertex } \\
\text { Temple } \\
\text { Temple \& vertex }\end{array}$ & $\begin{array}{l}3(20.00 \%) \\
7(46.67 \%) \\
3(20.00 \%) \\
2(13.33 \%)\end{array}$ & $\begin{array}{l}2(13.33 \%) \\
8(53.33 \%) \\
2(13.33 \%) \\
3(20.00 \%)\end{array}$ & Chi square test & 0.88 \\
\hline
\end{tabular}

$* \mathrm{P}$ value $<0.05$ was significant.

Only 5 patients $(16.67 \%)$ had positive pull test. There was no statistically significant difference between Norwood Hamilton classification in the two groups before treatment. As regards to presences of scaly scalp, presences of scars and pulling test results, there was no statistically significant difference between the two groups. There was no statistically significant difference between washing frequency, and cleaning methods in the two groups. None of the patients reported use of hair straighteners or dyes.

There was no statistically significant difference between the two groups as regards hair density at base line and at $6^{\text {th }}$ month of treatment. There was slight elevation in hair density but with no significant difference between hair density at the baseline and at $6^{\text {th }}$ month in group1. In group 2; there was small decline in hair density but with no significant difference between hair density at the baseline and at $6^{\text {th }}$ month. There was significant difference between the change in hair density between the two groups with positive change in group 1 (Table 3 ).

There was no statistically significant difference between the two groups as regards hair caliber at base line. However; there was statistically significant difference between the two groups as regards hair caliber at $6^{\text {th }}$ month of treatment. There was increase in hair caliber with significant difference between hair caliber at the baseline and at $6^{\text {th }}$ month in group 1. There was no significant difference between hair caliber at the baseline and at $6^{\text {th }}$ month of treatment in group 2 . There was highly significant difference between the change in hair caliber before and after treatment between the two groups (Table 4).

Table 3: Changes of hair density in the study groups before and after treatment.

\begin{tabular}{|c|c|c|c|c|}
\hline Variables & Group $1(n=15)$ & Group $2(n=15)$ & Statistical test & *P value \\
\hline $\begin{array}{l}\text { Hair density at base line: } \\
\text { Mean } \pm \text { SD } \\
\text { Median (range) }\end{array}$ & $\begin{array}{l}197.27 \pm 137.48 \\
200(11-400)\end{array}$ & $\begin{array}{l}189.07 \pm 143.1 \\
187.5(6-467)\end{array}$ & Mann-Whitney test & 0.76 \\
\hline $\begin{array}{l}\text { Hair density after } 6 \text { months: } \\
\text { Mean } \pm \text { SD } \\
\text { Median (range) }\end{array}$ & $\begin{array}{c}224.87 \pm 150.74 \\
227(36-480)\end{array}$ & $\begin{array}{l}180 \pm 130.48 \\
150(12-410)\end{array}$ & Mann-Whitney test & 0.39 \\
\hline $\begin{array}{c}P \text { value compared before and after } \\
\text { treatment }\end{array}$ & 0.08 & 0.65 & \multicolumn{2}{|c|}{ Wilcoxon Signed Rank test } \\
\hline $\begin{array}{l}\text { Hair density change: } \\
\text { Mean } \pm \text { SD } \\
\text { Median (range) }\end{array}$ & $\begin{array}{c}27.6 \pm 62.49 \\
25([-80]-170)\end{array}$ & $\begin{array}{l}{[-9.07] \pm 30.30} \\
0.5([-87]-22)\end{array}$ & Mann-Whitney test & 0.02 \\
\hline Hair density change percent: & $12 \%$ & $-4 \%$ & & 0.14 \\
\hline
\end{tabular}

$* \mathrm{P}$ value $<0.05$ was significant. 
SOHAG MEDICAL JOURNAL

Vol. 22 No.1 Jan 2018
Topical dutasteride with microneedling in treatment Marwa A. Abo Elmagd

Table 4: Changes of hair caliber width in the study groups before and after treatment.

\begin{tabular}{|c|c|c|c|c|}
\hline Variables & Group $1(n=15)$ & Group $2(n=15)$ & Statistical test & *P value \\
\hline $\begin{array}{l}\text { Hair caliber width at baseline: } \\
\text { Mean } \pm \text { SD } \\
\text { Median (range) }\end{array}$ & $\begin{array}{c}0.022 \pm 0.024 \\
0.018(0.002-0.086)\end{array}$ & $\begin{array}{c}0.020 \pm 0.016 \\
0.018(0.001-0.05)\end{array}$ & Mann-Whitney test & 0.90 \\
\hline $\begin{array}{l}\text { Hair caliber after } 6 \text { months: } \\
\text { Mean } \pm \text { SD } \\
\text { Median (range) }\end{array}$ & $\begin{array}{c}0.046 \pm 0.019 \\
0.42(0.014-0.078)\end{array}$ & $\begin{array}{c}0.020 \pm 0.013 \\
0.015(0.004-0.045)\end{array}$ & Mann-Whitney test & 0.001 \\
\hline $\begin{array}{c}P \text { value compared before and after } \\
\text { treatment }\end{array}$ & 0.005 & 0.69 & \multicolumn{2}{|c|}{ Wilcoxon Signed Rank test } \\
\hline $\begin{array}{l}\text { Hair caliber width change: } \\
\text { Mean } \pm \text { SD } \\
\text { Median (range) }\end{array}$ & $\begin{array}{c}0.023 \pm 0.024 \\
0.026([-0.022]-0.063)\end{array}$ & $\begin{array}{c}0.0003 \pm 0.015 \\
0.001([-0.027]-0.031)\end{array}$ & Mann-Whitney test & 0.003 \\
\hline Hair caliber change Percent & $98 \%$ & $3 \%$ & & 0.03 \\
\hline
\end{tabular}

$* \mathrm{P}$ value $<0.05$ was significant.

There was no statistically significant difference between the two groups as regards terminal/vellus ratio at base line and at $6^{\text {th }}$ month of treatment. There was elevation in terminal/vellus ratio with significant difference between terminal/vellus ratio at the baseline and at $6^{\text {th }}$ month in group 1 . There was no significant difference between terminal/vellus at the baseline and at $6^{\text {th }}$ month of treatment in group 2. There was highly significant difference between the change in terminal/vellus before and after treatment between the two groups (Table 5).

Table 5: Changes of hair terminal/vellus ratio in the study groups before and after treatment.

\begin{tabular}{|c|c|c|c|c|}
\hline Variables & Group $1(n=15)$ & Group $2(n=15)$ & Statistical test & *P value \\
\hline $\begin{array}{l}\text { Hair terminal/vellus ratio at } \\
\text { base line: } \\
\text { Mean } \pm \text { SD } \\
\text { Median (range) }\end{array}$ & $\begin{array}{c}3.99 \pm 5.08 \\
2.0(0.14-0.18)\end{array}$ & $\begin{array}{c}2.72 \pm 3.88 \\
1.75(0.14-15.4)\end{array}$ & $\begin{array}{c}\text { Mann-Whitney } \\
\text { test }\end{array}$ & 0.65 \\
\hline $\begin{array}{l}\text { Hair terminal/vellus ratio after } \\
6 \text { months: } \\
\text { Mean } \pm \text { SD } \\
\text { Median (range) }\end{array}$ & $\begin{array}{c}7.09 \pm 7.91 \\
2.45(0.15-22.2)\end{array}$ & $\begin{array}{c}2.89 \pm 5.06 \\
1.45(0.13-20)\end{array}$ & $\begin{array}{c}\text { Mann-Whitney } \\
\text { test }\end{array}$ & 0.15 \\
\hline $\begin{array}{c}\text { P value compared before and } \\
\text { after treatment }\end{array}$ & 0.005 & 0.73 & \multicolumn{2}{|c|}{ Wilcoxon Signed Rank test } \\
\hline $\begin{array}{l}\text { Hair terminal/vellus ratio } \\
\text { change: } \\
\text { Mean } \pm \text { SD } \\
\text { Median (range) }\end{array}$ & $\begin{array}{c}3.10 \pm 6.17 \\
0.4([-1.1]-20.2)\end{array}$ & $\begin{array}{c}0.17 \pm 1.40 \\
-0.005([-1.3]-4.6)\end{array}$ & $\begin{array}{c}\text { Mann-Whitney } \\
\text { test }\end{array}$ & 0.02 \\
\hline $\begin{array}{c}\text { Hair terminal/vellus ratio } \\
\text { change percent }\end{array}$ & $72 \%$ & $4 \%$ & & 0.02 \\
\hline
\end{tabular}

$* \mathrm{P}$ value $<0.05$ was significant.

There was statistically significant difference between the two groups as regards all parameters of the patient self-assessment questionnaire. The improvement and satisfaction were better in group 1 (Table 6).

Table 6: Comparison between the study groups according to self-assessment questionnaire.

\begin{tabular}{|c|c|c|c|c|}
\hline Variables & Group $1(n=15)$ & Group $2(n=15)$ & Statistical test & *P value \\
\hline $\begin{array}{l}\text { Bald spot getting smaller: } \\
\text { Agree } \\
\text { No opinion either way } \\
\text { Disagree } \\
\text { Strongly disagree }\end{array}$ & $\begin{array}{c}8(53.33 \%) \\
6(40.00 \%) \\
1(6.67 \%) \\
0\end{array}$ & $\begin{array}{c}0 \\
1(6.67 \%) \\
7(46.67 \%) \\
7(46.67 \%) \\
\end{array}$ & Chi square test & $<0.0001$ \\
\hline $\begin{array}{l}\text { Appearance of hair: } \\
\text { Somewhat better } \\
\text { A little better } \\
\text { Same } \\
\text { A little worse } \\
\end{array}$ & $\begin{array}{l}2(13.33 \%) \\
8(53.33 \%) \\
4(26.67 \%) \\
1(6.67 \%) \\
\end{array}$ & $\begin{array}{c}0 \\
2(13.33 \%) \\
10(66.67 \%) \\
3(20.00 \%) \\
\end{array}$ & Chi square test & 0.03 \\
\hline
\end{tabular}


SOHAG MEDICAL JOURNAL

Vol. 22 No.1 Jan 2018

\begin{tabular}{|c|c|c|c|c|}
\hline $\begin{array}{l}\text { Hair growth: } \\
\text { Greatly increase } \\
\text { Moderately increase } \\
\text { Slightly increases } \\
\text { No change } \\
\text { Slightly decrease }\end{array}$ & $\begin{array}{c}1(6.67 \%) \\
10(66.67 \%) \\
1(6.67 \%) \\
3(20.00 \%) \\
0\end{array}$ & $\begin{array}{c}0 \\
0 \\
6(40.00 \%) \\
7(46.67 \%) \\
2(13.33 \%)\end{array}$ & Chi square test & 0.001 \\
\hline $\begin{array}{l}\text { Slowing down hair loss: } \\
\text { Very effective } \\
\text { Somewhat effective } \\
\text { Not very effective } \\
\text { Not effective at all }\end{array}$ & $\begin{array}{c}5(33.33 \%) \\
8(53.33 \%) \\
1(6.67 \%) \\
1(6.67 \%)\end{array}$ & $\begin{array}{c}0 \\
2(13.33 \%) \\
8(53.33 \%) \\
5(33.33 \%)\end{array}$ & Chi square test & 0.001 \\
\hline $\begin{array}{l}\text { Satisfaction about hairline at the fr } \\
\text { of the head: } \\
\text { Very satisfied } \\
\text { Satisfied } \\
\text { Neutral } \\
\text { Dissatisfied } \\
\text { Very dissatisfied }\end{array}$ & $\begin{array}{c}0 \\
7(46.67 \%) \\
5(33.33 \%) \\
3(20.00 \%) \\
0 \\
\end{array}$ & $\begin{array}{c}0 \\
0 \\
3(20.00 \%) \\
2(13.33 \%) \\
10(66.67 \%) \\
\end{array}$ & Chi square test & 0.001 \\
\hline $\begin{array}{l}\text { Satisfaction about hair on the top: } \\
\text { Very satisfied } \\
\text { Satisfied } \\
\text { Neutral } \\
\text { Dissatisfied } \\
\text { Very dissatisfied }\end{array}$ & $\begin{array}{c}0 \\
5(33.33 \%) \\
10(66.67 \%) \\
0 \\
0 \\
\end{array}$ & $\begin{array}{c}0 \\
0 \\
0 \\
10(66.67 \%) \\
5(33.33 \%) \\
\end{array}$ & Chi square test & $<0.0001$ \\
\hline $\begin{array}{l}\text { Hair overall satisfaction: } \\
\text { Very satisfied } \\
\text { Satisfied } \\
\text { Neutral } \\
\text { Dissatisfied } \\
\text { Very dissatisfied }\end{array}$ & $\begin{array}{c}0 \\
5(33.33 \%) \\
7(46.67 \%) \\
3 / 15(20 \%) \\
0\end{array}$ & $\begin{array}{c}0 \\
0 \\
0 \\
10(66.67 \%) \\
5(33.33 \%)\end{array}$ & Chi square test & $<0.0001$ \\
\hline
\end{tabular}

* $\mathrm{P}$ value $<0.05$ was significant.

There was statistically significant difference between group 1 and group 2 as regards the investigator assessment $(\mathrm{p}$ value $=0.007$ ). Group 1 showed the highest prevalence of slight increase $9 / 15(60 \%)$, followed by no change $(4 / 15 ; 26.67 \%)$. However, these changes were not sufficient to produce change in the Norwood-Hamilton classification. In group $2 ; 13 / 15(86.67 \%)$ of the patients showed no change in hair density, one patient $(6.67 \%)$ showed slight increase, and the last patient $(6.67 \%)$ showed slight decrease (Table 7).

Table 7: Comparison between the study groups according to investigator assessment.

\begin{tabular}{|l|c|c|l|l|}
\hline \multicolumn{1}{|c|}{ Variables } & Group 1 $(\mathbf{n = 1 5})$ & Group 2 (n=15) & Statistical test & *P value \\
\hline Moderately increased & $1(6.67 \%)$ & 0 & & \\
Slight increased & $9(60.00 \%)$ & $1(6.67 \%)$ & Chi square test & 0.007 \\
No change & $4(26.67 \%)$ & $13(86.67 \%)$ & & \\
Slight decreased & $1(6.67 \%)$ & $1(6.67 \%)$ & & \\
\hline
\end{tabular}

$* \mathrm{P}$ value $<0.05$ was significant.

Side effects noted during the study were pain, headache and itching. There was no significant difference in adverse events between the two groups except for itching which was reported only in group 1; in $5(33.33 \%)$ of patients. The most frequent local side effect was pain, followed by mild headache. No cases were reported to have infection, ecchymosis, itching or puffed eyes (Table 8). No one of the patients complained of sexual disturbance, breast enlargement or tenderness

Testosterone and DHT levels were measured in group 1 only. Total testosterone was in the normal range $(0.47-9.8 \mathrm{ng} / \mathrm{ml})$; after treatment; there was increase in serum testosterone, but there was no statistically significant difference in mean testosterone level before and after treatment. DHT was in the normal range (250-990 pg/ml); after treatment; there was decline in serum DHT, but there was no statistically significant difference in mean of DHT level before and after treatment (Table 9). 
SOHAG MEDICAL JOURNAL

Vol. 22 No.1 Jan 2018

Table 8: Local side effects reported in the study groups.

\begin{tabular}{|l|c|c|c|c|}
\hline \multicolumn{1}{|c|}{ Variables } & Group 1 (n=15) & Group 2 $(\mathbf{n = 1 5})$ & Statistical test & *P value \\
\hline Pain & $13(86.67 \%)$ & $10(66.67 \%)$ & Fisher exact test & 0.39 \\
\hline Headache & $2(13.33 \%)$ & 0 & Fisher exact test & 0.48 \\
\hline Itching & $5(33.33 \%)$ & 0 & Fisher exact test & $\mathbf{0 . 0 4}$ \\
\hline
\end{tabular}

$* \mathrm{P}$ value $<0.05$ was significant.

Table 9: Hormonal level before and after treatment in group $1(n=15)$.

\begin{tabular}{|l|c|c|c|c|c|c|}
\hline \multicolumn{1}{|c|}{ Variables } & Before & After & Change & $\begin{array}{c}\text { Change } \\
\text { percent }\end{array}$ & $\begin{array}{c}\text { Statistical } \\
\text { test }\end{array}$ & $\begin{array}{c}* \mathbf{P} \\
\text { value }\end{array}$ \\
\hline $\begin{array}{l}\text { Total Testosterone } \\
(\mathbf{n g} / \mathbf{m l}):\end{array}$ & & & & & & \\
Mean \pm SD & $5.36 \pm 1.02$ & $5.50 \pm 0.96$ & $0.15 \pm 0.59$ & $2.6 \%$ & $\begin{array}{c}\text { Paired } \\
\text { sample t } \\
\text { test }\end{array}$ & 0.36 \\
Median (range) & $5.3(3.8-7.3)$ & $5.8(4-7.4)$ & $0.2([-0.9]-1.5)$ & & & Wilcoxon \\
\hline $\begin{array}{l}\text { Dihydrotestosterone } \\
(\mathbf{p g} / \mathbf{m l}):\end{array}$ & & & & & \\
$\begin{array}{l}\text { Mean } \pm \text { SD } \\
\text { Median (range) }\end{array}$ & $381.6 \pm 131.85$ & $359.6 \pm 146.23$ & $\begin{array}{c}\text { Signed } \\
{[-22] \pm 40.60}\end{array}$ & 0.06 \\
\hline
\end{tabular}

$* \mathrm{P}<0.05$ was significant.

\section{Discussion}

The psychosocial impact of AGA may negatively affect patient's quality of life and can lead to personal social and jobrelated problems ${ }^{(2)}$. Oral DST showed promising results in treatment of male AGA, but its use is limited by its side effects. So the possibility of using DST topically with scalp MN would have some advantages ${ }^{(\mathbf{1 0})}$.

In the present study, the mean age of the patients was $26.37 \pm 4.31$ years; with mean duration of hair loss was $5.00 \pm 2.28$ years. There was no significant difference between the study groups as respect to age, duration of baldness and family history.

In the current study; analysis of results of trichoscope at baseline showed no statistical differences in hair density, hair shaft diameter and terminal/ vellus ratio between two groups. After 24 week, group 1 showed improvement in hair density with mean percentage of change $(12 \%)$, but not to the extent of being statistically significant. This can be explained by that anagen phase of scalp hair growth has duration of several years. Therefore, it is possible that longer observation period is needed to obtain significant findings of regrowth of new scalp hair. Regarding group 2 (MN alone); there was statistically insignificant decrease in hair density with mean percentage of change $(-4 \%)$ after treatment. This decrease can be taken as the "normal" hair loss with AGA, so patients go bald despite therapy.

To the best of our knowledge, it is the first study to evaluate the efficacy of topical DST with MN in AGA. However; as regards DST mesotherapy, our results are consistent with a previous study by Abdallah et al. ${ }^{(8)}$ that reported a significant increase in the mean hair count by $(7.7391 \pm 0.104)$ in 14 male patients with AGA treated for 3 months with mesotherapy using DST 0.05- 
containing solution (with D-panthenol, biotin and pyridoxine). Also; a more recent study on 5 men with AGA; treated with mesotherapy using DST $(0.01 \%)$; reported increase of both hair density and hair shaft diameter in trichoscopy after 3 sessions of mesotherapy (one-session treatment every three months) ${ }^{(10)}$.

On the other hand; as regards $\mathrm{MN}$ in treatment of male AGA, increased hair count was previously reported by Dhurat et al. ${ }^{(6)}$ who found that MN along with minoxidil-treated group was statistically superior to minoxidil alonetreated group in promoting hair growth in men. The mean change in hair count after 3 months was significantly greater for the MN group compared to the minoxidil group (91.4 versus 22.2 respectively).

Concerning hair shaft diameter in the present study; group 1 showed $98 \%$ as a mean percentage of increase in hair shaft diameter, while group 2 showed minimal statistically insignificant increase with mean percentage of change $(3 \%)$. This enforces the added value of DST with MN on the MN alone in treatment of AGA. The increase in the hair shaft diameter in $\mathrm{MN}$ alone group goes with the alleged role of trauma of $\mathrm{MN}$ in improvement of AGA (9)

These results are consistent with a previous study on DST mesotherapy using trichogram; which reported statistically significant increase in hair shaft diameter in patients with male AGA receiving mesotherapy with DST (0.05\%)-containing solution, and in patients with receiving mesotherapy with pure DST $(0.005 \%){ }^{(9)}$. The authors also reported mild statistically insignificant increase in mean hair shaft diameter in patients receiving mesotherapy with saline, this goes with the alleged role of trauma of mesotherapy injection in improvement of $\mathrm{AGA}^{(9)}$.
Concerning terminal/ vellus ratio, group 1 showed statistically significant increase by $(72 \%)$ as a mean percentage of change, versus (4\%) mean percentage of change in group 2 which was mild and not statistically significant. The increase in the number of terminal hair in the group 1 suggests a role of DST in reversing the miniaturization process. The minimal improvement noticed in group 2 treated by $\mathrm{MN}$ only might be attributed to stimulation of hair growth by the trauma which increases the blood supply to the HF, but it was minimal and not clinically or statistically significant. To the best of our knowledge, none of the previous studies on DST mesotherapy of or $\mathrm{MN}$ commented on changes in terminal/ vellus ratio.

Concerning patient's self-assessment, as regard to bald spot getting smaller, hair appearance, hair growth, slowing down hair loss and satisfaction about hair, at the front, on the top and overall satisfaction. Group 1 showed statistically significant difference than group 2.

In group 1, the most prominent effect reported by the patients was slowing down hair loss in 13/15 (86.67\%) patients, followed by moderate increase in hair growth in 10/15 (66.67\%). Slowing down of hair loss and increase in hair growth in group 1, was mostly due to modification of hair cycle dynamics in response to DST resulting in prolongation of anagen phase, and so fewer hairs are in telogen phase.

The overall satisfaction in group 1 showed that $5 / 15(33.33 \%)$ of patients were satisfied and 7/15 (46.67\%) were neutral. This may be related to the impact of the disease on the psychological and social activities of patients, thereby reducing their quality of life ${ }^{(17)}$. Regarding patient's self-assessment; our results agreed with a previous study by Abdallah et al. ${ }^{(8)}$ on 14 male patients with AGA treated with mesotherapy using DST 0.05- containing solution; as 
6/14 (42.86\%) of the patients reported above $50 \%$ improvement in hair growth with significant decrease in the rate of hair fall, and 13/14 (92.9\%) showed improvement more than $50 \%$ in scalp covering.

On the contrary; patients selfassessment in the study by Sobhy et al. (9) reported no statistically significant difference between the three groups (mesotherapy of pure DST $0.005 \%$, DST 0.05-containing solution, and placebo) regarding satisfaction due to cessation of hair loss and the noticed improvement. This may be related to the psychological aspect of therapy ${ }^{(\mathbf{9})}$.

As regard the investigator assessment; 9/15 (60\%) in group 1 showed slight increase in the hair density however, not sufficient to produce change in the Norwood-Hamilton classification. There was a statistically significant difference favoring group1 than group 2 in which $13 / 15(86.67 \%)$ reported no change at all in hair density. The lack of change in the Norwood-Hamilton classification in our study may be explained by severer miniaturization of $\mathrm{HF}$ in frontal and temporal hairlines and regrowth of new scalp hair requires longer time for correction.

Evaluator assessment in a study by Dhurat et al. ${ }^{(6)}, 40 / 50$ (80\%) of the MN with minoxidil group showed improvement $(+2$ or +3 on the evaluator seven-point scale) compared to none $(0 / 50)$ of the minoxidil alone group. Another study by Dhurat and Mathapati ${ }^{(12)}$ evaluated the boosting effect of MN on four men with AGA who were on oral FIN and topical 5\% minoxidil therapy with no improvement. Authors reported that with the addition of $\mathrm{MN}$ along with the patients' ongoing therapy; investigators assessment was $(+2$ or +3 on the evaluator seven-point scale).

Based on the previous results which come in favour of $\mathrm{MN}$ along with minoxidil $5 \%^{(6)}$, or MN with FIN and minoxidil 5\% solution ${ }^{(12)}$, it might be suggested that hair growth in these studies not mainly due to $\mathrm{MN}$ monotherapy, but it may be due to coexisting FIN and minoxidil, which already have an approved role in terms of arresting of ongoing hair loss and new hair regrowth ${ }^{(8)}$.

Dermatologic side effects reported in the current study were minimal and did not differ between the two groups, except for itching which was reported only in group 1 in 5/15 (33.33\%) of patients and it may be related to topical DST. The most frequent dermatologic side effect was pain affecting $13 / 15(86.67 \%)$ of patients in group 1, and 10/15 (66.67\%) of patients in group 2. Pain was relieved shortly after the end of the session in almost all patients. Mild headache in was reported in 2/15 (13.33\%) in group 1 which lasted for one to two days. None of the patients reported tightness, infection, ecchymosis, or puffed eyes. These results are consistent with the previous study; of mesotherapy using DST-containing solutions; by Abdallah et al. ${ }^{(8)}$ which reported minimal side effects in the form of mild pain and headache.

In an attempt to evaluate the possibility of systemic absorption and the resulting systemic side effects in group 1, none of the 15 patients complained of decreased libido, erectile or ejaculatory dysfunction or breast enlargement and tenderness. This suggests the potential safety of local DST. These results were in agreement with the previously reported results of safety of mesotherapy with $\operatorname{DST}^{(\mathbf{8 , 9})}$.

However; when compared with oral DST used in a study carried by Andriole and Kirby ${ }^{(18)}$, who reported a modestly elevated incidence of erectile dysfunction, decreased libido, ejaculation disorders, and gynaecomastia in the group who received DST $0.5 \mathrm{mg} /$ day and that was statistically significant as compared to 
placebo. On the contrary; Eun et al. revealed that no significant difference was observed between the two studied groups (group received $0.5 \mathrm{mg} /$ day DST and group received placebo) in terms of sexual function.

In addition to confirm safety of topical DST and the possibility of systemic absorption, assessment of serum testosterone and DHT were done. There was decline in serum DHT after treatment with minimal increase in serum testosterone levels, although systemic absorption took place but the change was statistically insignificant, and the levels were still in the normal range. This could be attributed to the wide normal range of serum testosterone (0.47-9.8 ng/ml) and DHT (250-990 $\mathrm{pg} / \mathrm{ml})$.

These results matched with the previously mentioned results by Sobhy et al. (9) with mesotherapy using DSTcontaining solutions. However; when compared with systemic DST therapy, a

\section{References}

1. Muller DC, Giles GG, Sinclair R, Hopper JL, English DR: Age-dependent associations between androgenetic alopecia and prostate cancer risk. Cancer Epidemiol Biomarkers Prev. 2013; 22(2): 209-15.

2. Hunt $\mathbf{N}$ and Mchale $\mathbf{S}$ : The psychological impact of alopecia. BMJ. 2005; 331(7522): 951-3.

\section{Gubelin Harcha W, Barboza Martinez} J, Tsai TF, Katsuoka K, Kawashima M: A randomized, active- and placebocontrolled study of the efficacy and safety of different doses of dutasteride versus placebo and finasteride in the treatment of male subjects with androgenetic alopecia. $J$ Am Acad Dermatol. 2014; 70(3): 489498.e3.

4. Kim MW, Shin IS, Yoon HS, Cho S and Park HS: Lipid profile in patients with androgenetic alopecia: a meta-analysis. $J$ Eur Acad Dermatol Venereol. 2017; 31(6): 942-951. previous study conducted by Amory et al. ${ }^{\text {(20); }}$ on 99 healthy men receiveing 0.5 mg DST; documented significantly suppression in serum DHT and transiently increase serum testosterone. Also Olsen (21) found that scalp and serum DHT levels significantly decreased, and testosterone levels significantly increased after systemic DST.

Limitations of our study were the small sample size and the short follow-up period. Further studies with larger number of patients are recommended. In conclusion; topical DST with $\mathrm{MN}$ is a promising tool in $\mathrm{HF}$ stimulation in male AGA resulting in reduction or cessation of hair loss and partially promotion of new hair growth. The role of trauma or therapeutic wounding of $\mathrm{MN}$ is mild in treatment of male AGA, and MN should not be used as monotherapy but MN may add value when combined with other therapies.

5. Gkini MA, Kouskoukis AE, Tripsianis G, Rigopoulos D and Kouskoukis K: Study of platelet-rich plasma injections in the treatment of androgenetic alopecia through an one-year period. J Cutan Aesthet Surg. 2014; 7(4): 213-9.

6. Dhurat R, Sukesh M, Avhad G, Dandale A, Pal A: A randomized evaluator blinded study of effect of microneedling in androgenetic alopecia: a pilot study. Int $J$ Trichology. 2013; 5(1): 6-11.

7. Arif T, Dorjay K, Adil M and Sami M: Dutasteride in Androgenetic Alopecia: An Update. Curr Clin Pharmacol. 2017; 12(1): 31-35.

\section{Abdallah M, El-Zawahry $\mathrm{K}$ and Besar H: Mesotherapy using dutasteride- containing solution in male pattern hair loss: A controlled pilot study. J Pan Arab Leag Dermatol. 2009; 20: 137-45.}

9. Sobhy N, Aly H, El Shafee A and El Deeb M: Evaluation of the effect of injection of dutasteride as mesotherapeutic 
tool in treatment of androgenetic alopecia in males. Our Dermatol Online. 2013; 4(1): 40-5.

10. Saceda-Corralo D, Rodrigues-Barata AR, Vano-Galvan S and Jaen-Olasolo P: Mesotherapy with Dutasteride in the Treatment of Androgenetic Alopecia. Int J Trichology. 2017; 9(3): 143-145.

11. Fertig RM and Gamret AC: Microneedling for the treatment of hair loss? 2017.

12. Dhurat $\mathbf{R}$ and Mathapati S: Response to Microneedling Treatment in Men with Androgenetic Alopecia Who Failed to Respond to Conventional Therapy. Indian J Dermatol. 2015; 60(3): 260-3.

13. Shapiro J, Wiseman $M$ and Lui $H$ : Practical management of hair loss. Can Fam Physician. 2000; 46: 1469-77.

14. Sehgal VN, Kak R, Aggarwal A, Srivastava G and Rajput P: Male pattern androgenetic alopecia in an Indian context: a perspective study. $J$ Eur Acad Dermatol Venereol. 2007; 21(4): 473-9.

15. Barber B, Kaufman $K$, Kozloff $R$, Girman C and Guess H: A hair growth questionnaire for use in the evaluation of therapeutic effects in men. $J$ Dermatol Treat. 1998; 9(3): 181-186.
16. Lucky AW, Piacquadio DJ, Ditre CM, Dunlap F, Kantor I: A randomized, placebo-controlled trial of $5 \%$ and $2 \%$ topical minoxidil solutions in the treatment of female pattern hair loss. J Am Acad Dermatol. 2004; 50(4): 541-53.

17. Mounsey AL and Reed SW: Diagnosing and treating hair loss. Am Fam Physician. 2009; 80(4): 356-62.

18. Andriole GL and Kirby R: Safety and tolerability of the dual 5alpha-reductase inhibitor dutasteride in the treatment of benign prostatic hyperplasia. Eur Urol. 2003; 44(1): 82-8.

19. Eun HC, Kwon OS, Yeon JH, Shin HS, Kim BY: Efficacy, safety, and tolerability of dutasteride $0.5 \mathrm{mg}$ once daily in male patients with male pattern hair loss: a randomized, double-blind, placebocontrolled, phase III study. J Am Acad Dermatol. 2010; 63(2): 252-8.

20. Amory JK, Wang C, Swerdloff RS, Anawalt BD, Matsumoto AM: The effect of 5alpha-reductase inhibition with dutasteride and finasteride on semen parameters and serum hormones in healthy men. J Clin Endocrinol Metab. 2007; 92(5): 1659-65.

21. Olsen EA: Female pattern hair loss. $J$ Am Acad Dermatol. 2001; 45(3 Suppl): S70-80. 
SOHAG MEDICAL JOURNAL

Vol. 22 No.1 Jan 2018
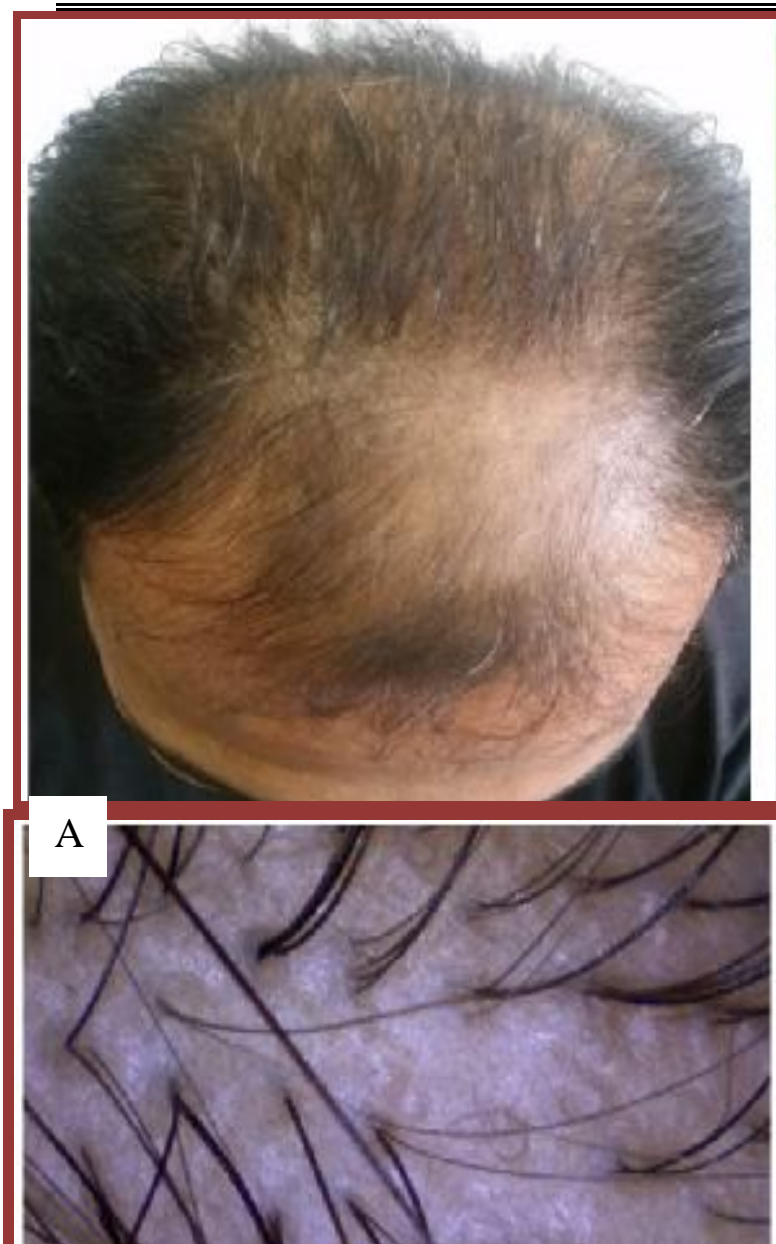

(M.

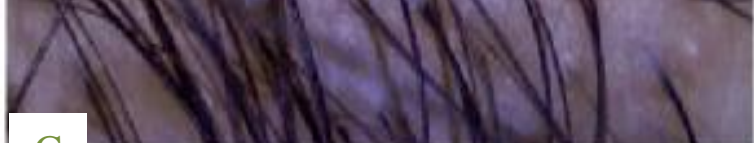

C

Figure 1: 32 years old male patient with AGA stage IV treated with microneedling with dutsteride. A-

Clinical photo at baseline, B- Clinical photo after 6 month of treatment showing significant hair regrowth, C-

Trichoscopic image (x50 folds) showing hair diameter heterogeneity and peripilar sign at the baseline, D-

Trichoscopic image (x50 folds) after 6 months of treatment showing increased hair density per $\mathrm{cm}^{2}$. 
SOHAG MEDICAL JOURNAL

Vol. 22 No.1 Jan 2018

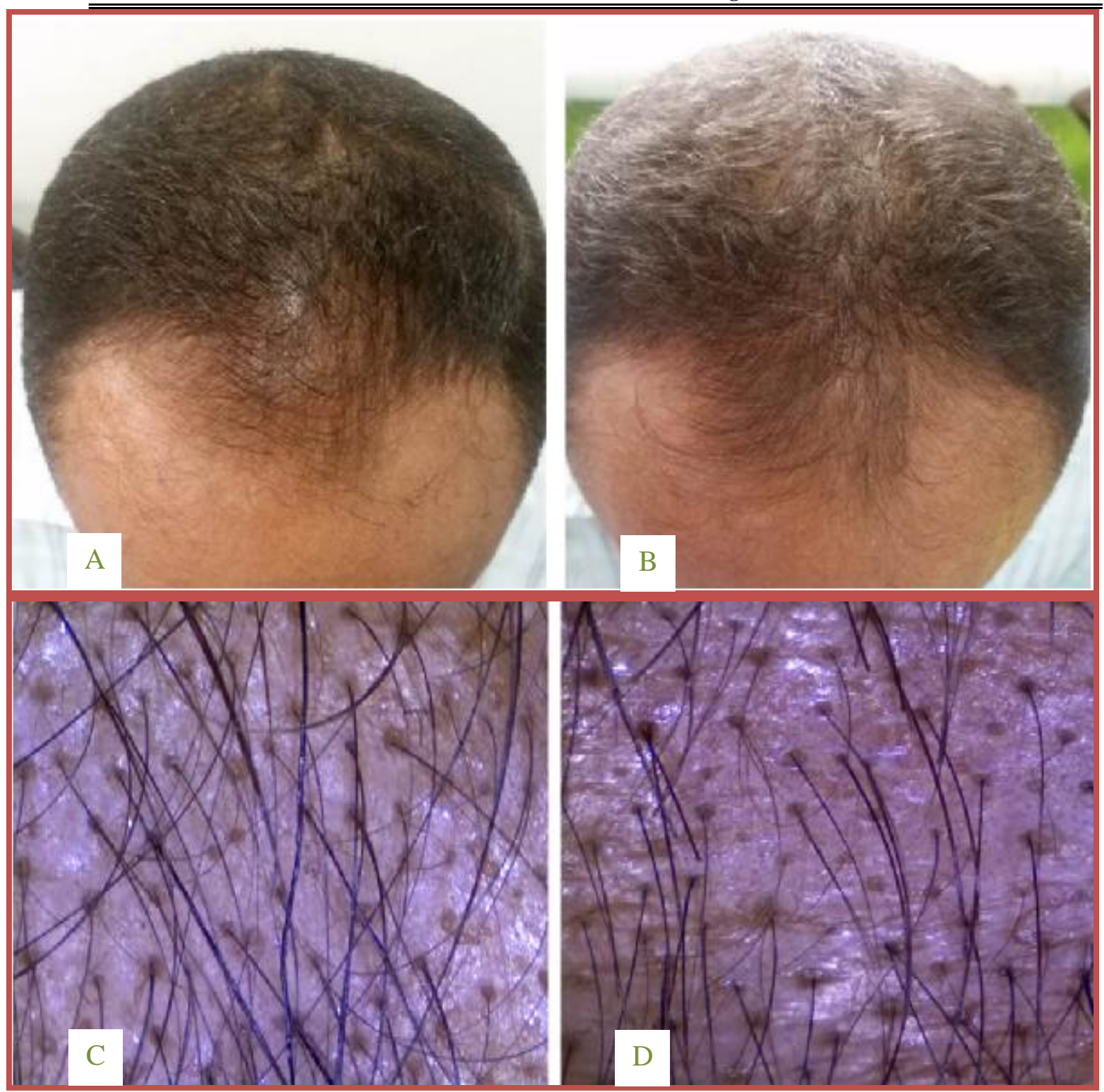

Figure 2: 29 years old male patient with AGA stage III treated with microneedling alone. A- Clinical photo at baseline, B- Clinical photo after 6 month of treatment showing no significant difference between all hair parameter before and after treatment, $\mathbf{C}$ -

Trichoscopic image (x50 folds) showing hair diameter heterogeneity, significant number of thin hair with single follicular unit at the baseline, D- Trichoscopic image (x50 folds) after 6 months of treatment showing no significant difference between all hair parameter before and after treatment. 
SOHAG MEDICAL JOURNAL

Vol. 22 No.1 Jan 2018 